\title{
A New Demographic Situation and Problems of Employment in Uzbekistan
}

\author{
Sh M Rakhmatullaev ${ }^{1}$ and Sh Y Salimov ${ }^{2 *}$ \\ ${ }^{1}$ Department of Historical Sciences, Uzbekistan \\ ${ }^{2}$ Department of Scientific Research, Uzbekistan
}

Received: 眥 September 07, 2018; Published: 㠿 September 12, 2018

*Corresponding author: Sh Y Salimov, Scientific researcher at Scientific and Enlightenment Memorial Complex, Uzbekistan

\author{
Abstract \\ The article analyzes the characteristics, indicators and factors of the demographic situation in Uzbekistan, the impact of \\ demographic processes on the definition of the current state and perspective directions of the country's socio-economic development \\ have been analyzed.
}

Keywords: Demographic situation; Population composition; Labor resources; Demographic policy; Economic and social processes; Natural growth of the population

\section{Introduction}

The historical realities of the current situation at the end of the $\mathrm{XX}$ century in the post-Soviet area dictated the terms on formation of tasks and development of ways of transition to new methods of managing, creation of effective economy and providing on this basis socially acceptable living conditions of the population. At the same time identification and the solution of acute social issues, which Uzbekistan had to face, was the most important aspect of new managing. Under the influence of, first exogenous factors, in the republic in the late 1980's and the beginning of the 1990's was very difficult starting conditions, unlike other post-Soviet states. Years of domination of an excessively centralized control system left a lot of unresolved and the specific social and demographic problems inherent, which have accepted an extremely destructive character only in Uzbekistan. The formation of bringing in an economy with the raw orientation of export, a priority of all-union interests in the activity of the central ministries and departments in a question of development of an economic complex of the republic have had an adverse effect on a condition of the social sphere. How it is possible to explain differently that circumstance that in the presence in the republic of an excess labor requires more than one million workers have been involved in the needs of the enterprises of allied appointment to Uzbekistan from other republics. Because of such practice in Uzbekistan, the share of the unoccupied able-bodied population increased from year to year. The alternative calculations made in 1992 have confirmed the fact that in recent years existence of the USSR $14 \%$ of the efficient population of Uzbekistan had no work (in other Union republics this indicator did not exceed 5.5\%) [1].

The problem of unemployment was particularly acute in the most densely populated regions of Uzbekistan - the Fergana Valley. The densely populated of the valley exceeded value on the republic almost seven times. At the allied level, the Fergana valley was the leader in this indicator. So, for example, in 1990 on population density the Andijan region took first place in the USSR (427,4 people/sq.km), Fergana - the second (313,6 persons/sq.km), Namangan - the fifth $(197,2$ persons/sq.km) [2]. By the time of the finding of the state sovereignty of Uzbekistan, the economy of the republic has practically lost resistant ability to solve the sharp crisis phenomena in the social and demographic sphere, including decreases in the standard of living of the population and the increase in poverty. Especially it was shown in the village where the share of rural people in total number exceeded $60 \%$, and nearly $80 \%$ of an increase in population of Uzbekistan. By the end of the Soviet era, Uzbekistan had appeared in a vice of a so-called "Malthusian trap" [3] - influenced of high rates of an increase in population and a considerable share of the disabled population on welfare of society. Therefore, by estimates of economists, in 19851990 the increase in population absorbed $70 \%$ of a gain of national income of the republic [4]. 
With the declaration of independence, the population policy in Uzbekistan has undergone basic changes. First, it began to carry out for the benefit of the population, and education of the healthy younger generation became her main slogan. During implementation of large-scale reforms, including in the social sphere, in Uzbekistan there was a new demographic situation, which was characterized by the following tendencies:

i. Decrease in an absolute and relative increase in population of the republic;

ii. Reduction of birth rate and natural increase of the population;

iii. Noticeable decrease in child and maternal mortality;

iv. Increase in average life expectancy, population;

v. Migration outflow of the population from the republic.

Since the beginning of 2017, the population of Uzbekistan totaled over 32 million people. For years of independence (19912016), the population of the republic has increased approximately by 12 million people. Average annual rates of an increase in population during this period were from 1,5 to $1,7 \%$, and a pure average annual gain over 400 thousand people. For comparison, in 1980-1990 the average annual rate of an increase in population of Uzbekistan was 2,8\%. High absolute growth of population is necessary for the beginning of the 1990th years when it has approached 500 thousand people a year. 1991 also became the year of the highest natural increase of the population - about 600 thousand people. From the middle of the 1990th years the increase in population of the republic methodically began to decrease and in separate years made $1,2 \%$. Since 2006 , the increase in population has begun to rise. It is explained, first, by the intensive growth of the birth rate of the population during the perform period, which has provided rather stable growth of absolute number of women of fertile age. Secondly, the sustained economic growth promoting increase in welfare of the population.

In general, as it was noted in the national report on human development, promoted reduction of birth rates in Uzbekistan [5]:

a) Change of population policy at the level of the state,

b) The refusal of the previous Soviet strategy of material and moral incentive of possession of many children;

c) Change of policy in the field of public health care.

d) Reorientation of the population to the birth and education of healthy children due to increase in number of years between childbirth.

e) Stimulation of the birth of children by women at optimum age - from 20 to 30 years;
Considerable expansion of access for the population to contraceptives, including, provided on a free basis. Broad promotion of use of contraceptives for prevention of undesirable pregnancy; change of family installations of a considerable part of the population on restriction of birth rate in connection with difficulties of a transition period.

i. The last include a rise in price of life and material security of children and reduction of the public free services on keeping of children in preschool institutions;

ii. Change in many families of the habitual tenor of life in connection with migration, growth;

iii. Change of reproductive installations of women on the birth of smaller number of children in connection with the increased financial responsibility of families for education of children.

It is connected and with the increasing role of women in the formation of financial resources of the family budget now; influence of the universal tendencies of reduction of birth rates. It is separately necessary to allocate policy of the government of the Republic of Uzbekistan in the field of planning of family. In particular, of an action of the Ministry of Health of the republic for introduction of methods of contraception and promotion of restriction of birth rate, support at the level of the educational companies informing the population on need of planning of family. The main source of growth of population of Uzbekistan at the present stage is the natural increase, which considerably blocks the continuous migration outflow of the population from the republic in the last decades. Thereof in Uzbekistan, the new type of dynamics of populations in which the predominating role belongs to a natural increase has nowadays created.

Considering that the processes of updating in the republic have begun in a difficult situation, it was impossible to solve a complex of the social problems inherited or acquired during the disintegration of the former Union. Consequently, in the first years of independence owing to influence of several factors, first economically, not allowing to realize fully the basic principles and priorities of the social policy of the republic. Among them, it is possible to note the economic downturn at the initial stage caused by violation of economic communications and which has followed by a decrease in the employment rate, the psychological unpreparedness of the population to market reforms, etc. Demographic loaded together with economic problems have aggravated the employment problem, which was imminent during the Soviet era. The advancing growth rates of the population of the 1970-1980th years extremely negatively have affected character of a gain of ablebodied population in the 1990's and at the beginning of 2000 have aggravated a problem of employment of the population. 
In the conditions of temporary stagnation in the economy and the disintegration of traditional economic relations and other changes, according to official statistics data, during 1991-1993 the negative balance of labor workforce in the republic was about 440 thousand people [6]. According to local experts, to the middle of the 1990th years in the agriculture of the republic 1,5 million "excess hands have collected" [7]. The tendency characteristic to the previous period, - falling of employment rate - has accepted character that is even more negative. For example, in 1990, at the time of inclusion of Uzbekistan in market economy from 10 million people, making the labor resources capacity of the republic 7,8 million, in 1991 - 8,3 million, in 1993 - 8 million [8] people have been involved in the national economy. In 2000 these indicators equaled, respectively, 12,4 million and 9,0 million [9] people. From here the share of employed in the economy in 2000 in relation to 1991 has considerably decreased - from 78 to $72 \%$. Reduction of total number of busy is caused by the following factors: transfer of many enterprises on various forms of ownership and managing; reduction of the outputs; elimination of a number of the institutions and organizations, which are not fitting in with, qualitatively other on a character state political system, economic structure. For example, because of reforms in the agrarian sector and transfer of agricultural enterprises from state farms and collective farms on more effective forms of managing the process of release of excess labor became more active. Only in 2000 from the healed and transformed into cooperatives agricultural enterprises over 100 thousand people have been released [10].

Besides, there were a number of the problems in social and economic development, which were also negatively influencing the nature of employment in the country. First, maintaining employment of workers at technically backward enterprises and productions with a prevalence of unqualified work, in turn affected their competitiveness. Secondly, imbalance of labor demand and her offer. It is confirmed by preservation of a constant number of open vacancies, in the presence of the registered unemployed who do not have an opportunity for employment in connection with insufficient professional qualifications. Thirdly, strengthening of tension in labor markets in certain areas and the cities of the Republics of Karakalpakstan, Navoiy, Surkhandarya, Khorezm and areas of the Fergana Valley in connection with insufficiency of a number of the entered jobs to the needs of the population of regions for employment.

According to experts, these factors characteristic of the initial stages of transformations have exerted negative impact on the formation of revenues of the state budget of the country, and, therefore, on income and the standard of living of the population. Occurred and during the separate periods inflationary processes amplified, the labor modulation from key branches of economy in enterprise structures. Especially an outflow of qualified personnel because of external migration not always was justified [11]. It has predetermined growth of relative and absolute number of the unemployed, aloof from officially taken the forms and forms of employment. Therefore, for example, the unemployment rate indicator in the country by the beginning of 2001 was about $7 \%$ [12]. In general, the main trends of quantitative changes in the sphere of employment of the able-bodied population are given in the following (Table 1) [13].

Table 1: Employment rate of the population of the Republic of Uzbekistan, thousand people.

\begin{tabular}{|c|c|c|c|c|c|c|c|c|}
\hline \multirow{2}{*}{ Indicators } & \multirow{2}{*}{1991} & \multirow{2}{*}{1995} & \multirow{2}{*}{2000} & \multirow{2}{*}{2005} & \multirow{2}{*}{2011} & \multirow{2}{*}{2015} & \multicolumn{2}{|c|}{ 2015/1991: } \\
\hline & & & & & & & $+/-$ & $\%$ \\
\hline $\begin{array}{l}\text { Population } \\
\text { size }\end{array}$ & 20608,0 & 22462,0 & 24488,0 & 26021,0 & 29123,3 & 31575,3 & $+10967,3$ & 141,3 \\
\hline $\begin{array}{l}\text { Number of } \\
\text { able-bodied } \\
\text { populations }\end{array}$ & 10237,7 & 10601,6 & 12941,5 & 15050,3 & 17309,8 & 18276,1 & $+8038,4$ & 169,1 \\
\hline $\begin{array}{l}\text { Employment } \\
\text { rate }\end{array}$ & 8255,0 & 8449,2 & 8983,0 & 10196,3 & 11919,1 & 13058,3 & $+4803,3$ & 144,4 \\
\hline $\begin{array}{c}\text { Coefficient } \\
\text { of the } \\
\text { employment, } \\
\%\end{array}$ & 40,1 & 37,6 & 36,7 & 39,2 & 40,9 & 41,3 & $+1,2$ & - \\
\hline $\begin{array}{l}\text { Employment } \\
\text { rate of } \\
\text { able-bodied } \\
\text { population, \% }\end{array}$ & 80,6 & 79,7 & 69,4 & 67,7 & 68,9 & 71,4 & $-9,2$ & - \\
\hline
\end{tabular}

For 1991-2016 the gain of number of the able-bodied population, which has made over $70 \%$ is noted. Naturally, considering the specifics of conditions of the population of the country, it is possible to claim that her main gain occurred, generally at the expense of the country people of the republic. It aggravates a problem of employment of a labor resource in rural areas and consequently, the relevance of creation of new jobs in the village and increases in competitiveness of the labor force. As increase in a share of 30-39 and 40-49-year-old, men and women have predicted, in the long term will be relevant and questions not only the preparation and retraining of personnel of workers and experts, further increase in their qualification, employment, but also strengthening of their 
territorial mobility and migration. In this regard, the First President of the Republic of Uzbekistan I.A. Karimov, characterizing the social and demographic situation which has developed in the country, he emphasized: "Won't be a big exaggeration to say that owing to specific features of our country and, first of all demographic features, problems of employment of the population continue to keep the relevance and sharpness" [14].

These and other social economic problems, and the contradictions observed both in Uzbekistan and in other countries of the former Soviet Union, have introduced new types and forms of migration [15]. If to consider stages of processes of migration for the last two decades, then it is possible to notice sharp changes in their motives and orientation. Therefore, in the first half of the 1990th migration covered generally Russian-speaking population and other ethnic minorities re-emigrating on the historical homeland in connection with destabilization of the interethnic relations in all former Soviet Union [16]. However, from the second half of the 1990th migration gains obvious economic orientation and is caused by the aspiration of people to improve the financial position [17]. At the same time, modern external labor population, several socioeconomic factors and prerequisite causes it. Among them are an important tension of the labor market (especially in excess working regions) and a possibility of receiving rather high earnings in foreign markets. On the other hand, labor migration is of great importance for the country: she reduces the demographic pressure upon local labor markets, especially in densely populated regions, and serves as the essential factor reducing risks of poverty.

However, the bulk of labor migration occurs unorganized and has spontaneous character. Demand of the population for work abroad for the present considerably exceeds the available possibilities of organized export of labor.

Thus, to Uzbekistan, as well as all countries enduring a transitional stage of development practically all standard composite structures of unemployment were characteristic: frictional, structural and cyclic. Considering the developed situation in the country for first years, sovereign development, the state has built active policy in the sphere of employment: from expansion of a system of training and retraining, increases in investment into labor exchanges up to use of the budget, fiscal and monetary and credit control levers. Especially it was noticeable during an era of transition to phases of the moderate, then intensive development which has caused essential changes in labor market development.

The country leader based on the adopted state programs completely stimulated the steady growth of creation of jobs and employment of the population. For the last decade in Uzbekistan, the quantity of annually created jobs has significantly grown. Especially the rapid growth of scales of small business (from 31\% in 2000 up to nearly 56\% in 2014 of GDP, and from 49 to $76 \%$ - for the same period on number occupied in them) favors to a solution of the problem of employment and restriction of needy categories of the population. For example, only in 2014 in the sphere of small business and private business more than 480 thousand new jobs, or every second had been created. In general, the high demographic capacity and the relevant age structure of the population of Uzbekistan will remain also in the remote prospect that creates a number of the problems connected with employment of youth, improvement of structure of employment of economically active population, formation of structure and regulation of migration processes.

\section{References}

1. Uzbekistan: General assessment of the country UN (2003) C 11-12 Social Sciences in Uzbekistan 1989. Here too it is necessary to consider the fact connected with the traditional tenor of life that about a half of unoccupied women were housewives 1: 52 .

2. Rakhmatullaev Sh M (2016) Fargoona vodiysi shaharlarida iqtisodiy transformatsiya jarayonlari (1991-1996 yillar) - Tashkent.

3. The theory which is put forward by one of the theorists of classical economic school - Thomas Malthus (1766-1834) in the book "Experience about the Law of the Population".

4. Yusupov UB (1999) Formation and development of economic science. A course of lectures on stories of an economic thought since the most ancient times until the end of the 80th of the 20th century p. 64 .

5. Education in Uzbekistan (2016) supply and demand balance/National reports on human development. UNDP. $2007 / 2008$ p. 73.

6. The national economy of the Republic of Uzbekistan (1993) Annual statistics p. 23.

7. Murodov U, Saidakhmedov A (1999) Agrar islohot va qishloq iqtisodiyotini rivojlantirish // Economic Bulletin of Uzbekistan 7: 15.

8. (1993) Uzbekistan for years of independence Statistical collection p. 24.

9. (2001) The national economy of the Republic of Uzbekistan in 1993. Annual statistics. T 1995; Work and employment in the Republic of Uzbekistan. Statistical collection.

10. (2018) Central state archive of the Republic of Uzbekistan/ ЦГА РУз. Ф. М-15, оп. 1; ед. хр. 1104.

11. (2001) Uzbekistan: ten years on the way of formation of market economy T p. 277.

12. Central state archive of the Republic of Uzbekistan/ ЦГА РУз. Ф. М-15, оп.1, ед.хр. 947 , л. 86.

13. Mirzakarimova MM, Bandlikda ijtimoiy sheriklik T (2013) p. 130. Given for 2015 from the Statistical yearbook of regions of Uzbekistan. Statistical collection T: State Committee on statistics of the Republic of Uzbekistan, 2016 г р. 33.

14. Karimov IA (2012) Report at the meeting of the Cabinet of Ministers on the main results of 2011 and priorities of socio economic development for 2012 .

15. Seasonal, temporary, long-term, regional, border, legal and illegal, etc.

16. As practice has shown, the population immigrated not always developed favorably. So, according to some information, to the period from 1989 to 2004 in Russia from the neighboring countries, there have arrived about 5,5 million Russians from whom about 2 million, then have returned, having met on the historical homeland not only material difficulties, but also the malevolent relation from the state. (Transformation of migration processes in the post-Soviet era Under LL Rybakovsky's (eds.), M: The Institution of Russian Academy of Sciences, The Institute of Socio-Political Research RAS (2009) p. 17.

17. Murtazina RB (2007) Migration in Uzbekistan: modern situation and directions of her regulation // Social Sciences in Uzbekistan 6: 56. 
(c) This work is licensed under Creative

To Submit Your Article Click Here: Submit Article

DOI: 10.32474/PRJFGS.2018.02.000138

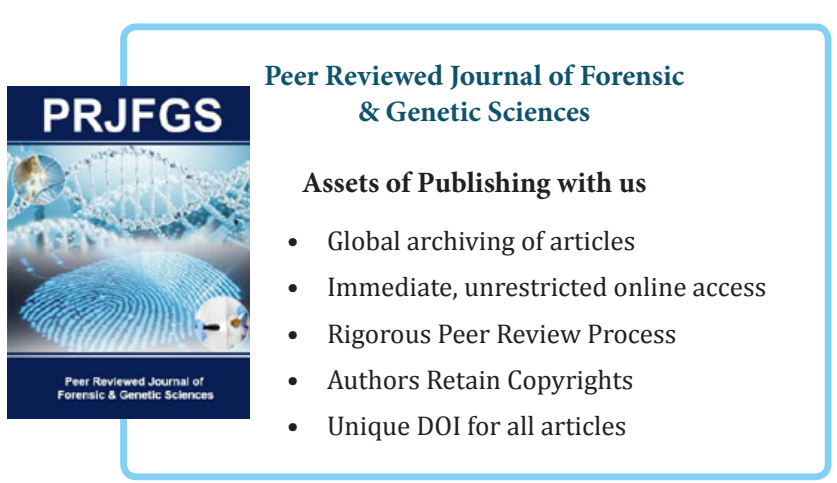

